\title{
The Impact of Secondary Phyllosilicate Minerals on the Engineering Properties of Various Igneous Aggregates from Greece
}

\author{
Petros Petrounias ${ }^{1, *(\mathbb{D})}$, Panagiota P. Giannakopoulou ${ }^{1}$, Aikaterini Rogkala ${ }^{1}$, \\ Paraskevi Lampropoulou ${ }^{1}$, Eleni Koutsopoulou ${ }^{1}$, Dimitrios Papoulis ${ }^{1}$, Basilios Tsikouras ${ }^{2}$ (10 \\ and Konstantin Hatzipanagiotou ${ }^{1}$ \\ 1 Section of Earth Materials, Department of Geology, University of Patras, 26504 Patras, Greece; \\ peny_giannakopoulou@windowslive.com (P.P.G.); krogkala@upatras.gr (A.R.); \\ p.lampropoulou@upatras.gr (P.L.); ekoutsop@upatras.gr (E.K.); papoulis@upatras.gr (D.P.); \\ k.hatzipanagiotou@upatras.gr (K.H.) \\ 2 Physical and Geological Sciences, Faculty of Science, Universiti Brunei Darussalam, Jalan Tungku Link, \\ Gadong BE1410, Brunei Darussalam; basilios.tsikouras@ubd.edu.bn \\ * Correspondence: Geo.plan@outlook.com
}

Received: 22 June 2018; Accepted: 27 July 2018; Published: 31 July 2018

\begin{abstract}
This paper investigates the effect of alteration on the physicomechanical properties of igneous rocks used as aggregates, from various areas from Greece. The studied lithologies include serpentinized dunites, serpentinized harzburgites, serpentinized lherzolites, metamorphic gabbros, diabases, dacites and andesites. Quantitative petrographic analysis shows that the tested samples display various percentages of secondary phyllosilicate minerals. Mineral quantification of the studied rock samples was performed by using the Rietveld method on X-ray diffraction patterns. The samples were also tested to assign moisture content $(w(\%))$, total porosity $\left(n_{t}(\%)\right)$, uniaxial compressive strength (UCS (MPa)) and Los Angeles abrasion test (LA (\%)). The influence of secondary phyllosilicate minerals on the physicomechanical behavior of the tested samples was determined using regression analysis and their derived equations. Regression analysis shows a positive relationship between the percentage of the phyllosilicate minerals of the rocks and the moisture content as well as with the total porosity values. In mafic and ultramafic rock samples, the relationships between the secondary phyllosilicate minerals and their physicomechanical properties have shown that the total amount of the secondary phyllosilicate minerals results negatively on their physicomechanical properties. On the other hand, the low percentage of phyllosilicate minerals in volcanic rocks can't be able to define their engineering properties.
\end{abstract}

Keywords: phyllosilicate minerals; serpentine; chlorite; clay minerals; aggregates; physicomechanical properties

\section{Introduction}

Building aggregates are essential raw materials for the construction industry, which are themselves rocks with a key role in creating, maintaining, and enhancing the built up environment. Aggregates are divided into natural stone aggregates (sand and gravel) and crushed aggregates (crushed stones). These materials are commonly used for construction purposes and can frequently be interchanged with one another. Good quality rocks, which can be used as natural aggregates are distributed throughout Greece in a wide variety of geological environments. Sand and gravel deposits are commonly the products of the weathering of bedrock and subsequent transportation and deposition of the material by water or ice. They commonly occur as river or stream deposits and in glaciated areas as glaciofluvial 
and other deposits. Crushed stone aggregates can be produced by a wide variety of parent bedrock materials [1]. The physicomechanical properties of aggregate particles are significant parameters in any application and in their assessment for engineering purposes. The increased number of construction failures has highlighted the importance of understanding their mineralogical features as a means to diagnose problems in engineering constructions. The physicomechanical properties of the aggregates depend on the mineralogical composition, textures (size, shape, and arrangement of mineral grains, nature of the grains contact, and degree of grain interlocking), degree of alteration, and deformation degree of the source rocks [2-7] in their classification for engineering purposes. Many researchers have studied the relationships between physical and mechanical tests in order to investigate the impact of the alteration degree of various rock samples or other petrographic characteristics (i.e., the structural complexity of serpentine) and how they affect the engineering properties of rocks [8-12]. Moreover, changes in textural characteristics affect their physicomechanical properties, which vary from excellent to fair, becoming poor to very poor when extensive alteration and intense deformation is present [13]. Increased percentages of certain secondary minerals, such as serpentine, chlorite, talc, and smectite affect negatively the physical as well as the mechanical properties of ultramafic aggregates due to their smooth layers, cleavage, and platy or fibrous crystal habit [10,14-16].

Primary minerals form during the original solidification (crystallization) of rocks. They include the varietal minerals which are used to assign a classification name to the rock as well as the accessory minerals present in lesser content. Secondary minerals are formed in a subsequent stage through processes such as weathering and hydrothermal alteration. Fresh igneous rocks without having sustained weathering or hydrothermal alteration have sufficient strength to meet any engineering requirement; the effect of ocean-floor metamorphism variously changes their physicomechanical properties [12]. Hydrothermal alteration can be isochemical, like metamorphism which is dominated by mineralogical changes only, or allochemical (metasomatism) which results in significant addition or removal of chemical elements. Intense allochemical alteration can result in significant volume changes, hence mass balance approaches using immobile elements as a reference are required to fully understand this process [17].

In the present study, the collected samples include ultramafic, mafic, and volcanic rocks, which have been exposed to supergene conditions [18-22] and metamorphic conditions and their main alteration products are phyllosilicate minerals. Phyllosilicates are an important group of minerals which includes serpentine, chlorite, micas, and clay minerals. The basic structure of the phyllosilicate is based on interconnected six-member rings of $\mathrm{SiO}_{4}{ }^{-4}$ tetrahedral that extend outward in infinite sheets. Various studies on the occurrence and the transformations of such phyllosilicate minerals have been published in the last 50 years. Phyllosilicate minerals are built from varying proportions of tetrahedral $(\mathrm{T})$ and octahedral $(\mathrm{O})$ layers, which are their basic building blocks. These layers may (or may not) coordinate with monovalent or divalent cations, thus eventually forming sheets, resulting in minerals of relatively similar structures but having different physical and chemical properties. As a result, there have been many different classifications of phyllosilicate group minerals reported in the literature [23]. In this study, the phyllosilicate minerals were studied as alteration products from each different petrographic group, namely ultramafic, mafic, and volcanic rock group. This classification allows the comparison of serpentine, mica, and swelling clay minerals (vermiculites and smectites), which show a gradual increase in complexity with regards to mineral structure.

Serpentine is the main alteration product of ultrabasic rocks [24], while chlorite may also be present in minor amounts. During this process, olivine and pyroxene transform to serpentine, a laminate soft mineral which belongs to the phyllosilicate subclass of minerals and forms smooth surfaces [24,25]. First-order changes to the major element composition of peridotites induced by serpentinization are the addition of 10-12 wt \% water and loss of $\mathrm{CaO}$ [26-28]. Among serpentine polymorphs, chrysotile shows a complex non-typical fibrous morphology. This and typical layered structure of the rest polymorphs have been proven to impart weakness to their host rocks [11]. Moreover, talc constitutes a secondary mineral which is formed by alteration of magnesium carbonates (magnesite and dolomite) 
and silicates such as serpentine, tremolite, and chlorite [29-32]. Salem [33] distinguished two types of ultramafic-derived talc ore; pure talc and chlorite-talc. He also proposed that the talc deposits hosted by ultrabasic rocks were formed through a process of regional metamorphism and thrust faulting of serpentinized ultramafic which was followed by percolation of hydrothermal solutions. Chlorite is the commonest and the most abundant secondary mineral of heated seawater-basic rocks as a result of substantive changes in the $\mathrm{Ca} / \mathrm{Mg}$ ratio of the reacting fluid. Chlorites have been extensively studied in metamorphic, igneous rocks [34,35], sedimentary rocks [36,37], and in geothermal systems as well as hydrothermal ore deposits [38-40]. The presence of chlorite in aggregates is known to have a critical effect on the freeze-thaw durability of concrete. Clay minerals are the common secondary minerals in volcanic rocks (e.g., andesites, rhyodacites). Clay group minerals show a high capacity to absorb and subsequently lose water, which is accompanied by swelling and shrinkage, respectively [41]. Therefore, the capacity of clay minerals to absorb large amounts of water, preferentially along their eminent cleavage, increases the requirement of water in a concrete mix, which in turn may have a detrimental impact on the workability of concrete and hence lead to a weaker and more permeable hardened concrete [38]. Generally, clays are also thought to reduce workability, due to their high surface areas and lamellar structure. Clay minerals have low strength and as a result, if they are present as a coating on aggregates, they might disrupt the bond between the aggregate and the cement paste of the produced concrete. For these reasons, it is of great importance to determine the presence of clay minerals in the aggregates [42-47].

This study aims to investigate the effect of petrographic characteristics of aggregates on their performance based on the results of physicomechanical tests and quantitative analysis of mineralogical composition by the Rietveld method [42,43] in the X-ray diffraction (XRD) patterns of the bulk rock. More specifically, this paper focuses on the relationship between the engineering properties of the studied aggregates and the ocean-floor alteration products for ultramafic and mafic rocks, as well as the weathering process products in volcanic rocks including mainly the type and percentage of phyllosilicate minerals.

\section{Geological Setting}

In this study, representative ultramafic and mafic rocks deriving from four ophiolite complexes of Greece and volcanic rocks from their surrounding areas were collected in order to study the influence of their alteration degree and especially the impact of their phyllosilicate secondary minerals on their physicomechanical properties. The Veria-Naousa ophiolite complex is located in northern Greece and belongs to the Almopias subzone of the Axios geotectonic zone. This complex consists, from base to top, from intense serpentinized lherzolite (BE.103) and harzburgite, crosscut by a few pyroxenitic dykes [48], as well as gabbro, diabase (BE.43) and pillow basalt. A large number of joints indicate that serpentinized peridotites are highly affected by tectonic processes. The Edessa ophiolite represents remnants of oceanic lithosphere, which was thrust out of one or more ocean basins during the Upper Jurassic to the Lower Cretaceous time [49,50]. It is tectonically very complex and consists of several tectonic units [51,52]. The ophiolitic complex includes lherzolite, serpentinized harzburgite (ED.59, ED.115) with a high degree of serpentinization, diorite, metamorphic gabbro (ED.26), diabase (ED.24, ED.110), and basalt. It is dismembered and scattered due to intensive tectonism. Intermediate to acidic volcanic rocks occur to the east of the ophiolitic complex and they belong to the Almopias subzone. They were created during the Pliocenic time and Nd-Sr isotopic composition suggest that they are partial melting products of the mantle wedge in a geotectonic regime associated to a supra subduction zone (SSZ) (andesites-BE.81, BE.82, BE.101) [53,54]. The Gerania ophiolite complex belongs to the Pelagonian geotectonic zone and is an incomplete and dismembered ophiolite sequence consisting mainly of variably altered Harzburgite, lherzolite (GE.42), and dunite (GE.37) variably altered [55-57]. The serpentinized peridotites are interrupted by gabbro dykes. The Middle-Late Jurassic Guevgueli Complex represents one of the main ophiolitic complexes of the Vardar Zone and has been sub-divided into two distinct sub-units, which are the East and the West Guevgueli, both including intrusive and 
volcanic sequences crosscut by several dykes. This complex is intruded by the Fanos Granite and with this together, is sandwiched, by a north-south striking thrust zone, between the Serbomacedonian Massif, to the east and the Paikon Unit, to the west. The gabbroic rocks of both West and East Guevgueli include olivine gabbro, amphibole gabbro, and diorite and their fine-grained varieties (diabases-KIL.2, KIL.3) [58,59]. The Agioi Theodori volcanic rocks, derived from the Crommyonia mark of the western end of the south Aegean volcanic arc includes outcrops of Pliocene dacites (GE.22, GE.23) which appear spatially related to extensional faults at the margin of the Saronicos basin [60].

\section{Materials and Methods}

In order to investigate the influence of petrographic characteristics on the engineering properties of aggregate rocks, ultramafic, mafic, and intermediate-acidic volcanic aggregate blocks were collected from quarries and other outcrops according to the EN 932-1 [61] standard. The samples were subsequently crushed in the appropriate gradations, in order to be suitable for all the engineering tests, which were performed according to European and International standards.

The petrographic features of the samples were examined using a combination of methods. Their mineralogical and textural characteristics were examined in thin sections using a polarizing microscope (Leitz Ortholux II POL-BK Ltd., Midland, ON, Canada) according to EN-932-3 [62] standard for petrographic description of aggregates. The mineralogical composition of the studied samples was also determined by XRD, which is considered the best technique to identify and quantify all minerals present in the studied rock samples. The Rietveld refinement method in XRD quantitative phase analysis has presented advantages over conventional ones [42-47]. The knowledge of the proportion of each phase is an important requirement in assessing the potential use of rocks as aggregates. The mineralogical composition of the studied samples was determined with X-ray diffraction using a Bruker D8 advance diffractometer with Ni-filtered $\mathrm{CuK}_{\alpha}$ radiation. Random powder mounts were prepared by gently pressing the powder into the cavity holder. The scanning area for bulk mineralogy of specimens covered the $2 \theta$ interval $2-70^{\circ}$, with a scanning angle step size of $0.015^{\circ}$ and a time step of $0.1 \mathrm{~s}$. The $<2 \mu \mathrm{m}$ clay fraction was separated by settling and dried on glass slides at room temperature. For each $<2 \mu \mathrm{m}$ specimen, the clay minerals were scanned from $2^{\circ}$ to $30^{\circ} 2 \theta$ and identified from three XRD patterns (after air-drying at $25{ }^{\circ} \mathrm{C}$, after ethylene glycol treatment and heating at $490{ }^{\circ} \mathrm{C}$ for $2 \mathrm{~h}$ ). The mineral phases were determined using the DIFFRACplus EVA $12^{\circledR}$ software (Bruker-AXS, $\mathrm{GmbH}$, Karlsruhe, Germany) based on the ICDD Powder Diffraction File of PDF-2 2006 while the semi-quantitative analyses was performed with the TOPAS 3.0 ${ }^{\circledR}$ software, based on the Rietveld method refinement routine. The routine is based on the calculation of a single mineral-phase pattern according to the crystalline structure of the respective mineral, and the refinement of the pattern using a non-linear least squares routine. The quantification errors were calculated for each phase according to Bish and Post $[43,44]$.

The surface texture of the samples, the clay minerals morphology, and the chemical composition of the minerals were examined using a scanning electron microscope SEM JEOL 6300 (JEOL, Tokyo, Japan) equipped with an energy dispersive spectrometer (EDS). The chemical composition of the minerals was determined using natural and synthetic standards and $20 \mathrm{kV}$ accelerating voltage with $3 \mathrm{nA}$ beam current. Sample grains were gold coated and analyzed using secondary electron images (SEI) to determine their surface texture according to BS 812 Part 1 [63] which outlines six qualitative categories, glassy, smooth, granular, rough, crystalline, honeycomb, and porous. Microanalyses were performed on polished gold or carbon coated thin sections, and sample grains mounted directly on the sample holder.

The physicomechanical properties of the ultramafic, mafic, and intermediate-acidic volcanic rocks were determined by the following laboratory tests: moisture content, total porosity, uniaxial compressive strength, and Los Angeles abrasion value. Moisture content $(w)$ is an important physical parameter for the quality of aggregates. In this study moisture content $(w)$ was measured in accordance with the AASHTO T-255 [64] standard. total porosity $\left(n_{t}\right)$ is a basic factor for rock strength, as a small 
change in pore volume can leads to an appreciable mechanical effect. This parameter was calculated according to the I.S.R.M [65] standard. The Los Angeles abrasion $(L A)$ test measures the resistance of aggregates in abrasion, attrition, and grinding, indicating that the lower $L A$ values of rocks correspond to more resistant rocks in abrasion and attrition. This test was carried out in accordance with the ASTM C-131 [66] standard using the "B" gradation. The uniaxial compressive strength (UCS) is one of the most significant engineering properties of rocks. The UCS test was carried out on six cylindrical rock specimens with height/diameter ratio between 2 and 3, and their diameters ranging from 51 to $54 \mathrm{~mm}$ (ASTM D-2938 [67]) and the average values were used for each set of specimens, indicating that higher values of UCS correspond to higher strength rocks.

\section{Results}

\subsection{Petrographic Features}

The studied ultramafic samples comprise serpentinized dunite (GE.37), harzburgite (ED.59, ED.115), and serpentinized lherzolite (BE.103, GE.42) with variable degrees of alteration. Dunite presents cataclastic and locally granular textures. Primary assemblage includes mostly olivine (forsteritic) and scarce relic crystals of orthopyroxene (Figure 1a). Infrequent opaque minerals (mainly chromite) are present, too. The primary assemblage of the harzburgite constitutes less than $20 \%$ of the mode and comprises relics of orthopyroxene, rare clinopyroxene, olivine, and Cr-spinel. The serpentinized lherzolite shows cataclastic, porphyroclastic and locally protogranular textures, the primary assemblage includes olivine (forsteritic), orthopyroxene, and clinopyroxene. Opaque minerals (mainly Al-spinel) are present in small amounts. Serpentine is the main alteration product of all samples (Figure 1b), showing mesh, ribbon, bastite, and intersertal textures. Chlorite, talc, and magnetite are also products of hydrothermal alteration.

The studied mafic samples comprise diabase (BE.43, ED.110, KIL.2, ED.24 and KIL.3) and metamorphic gabbro (ED.26). The diabase samples exhibit porphyritic, ophitic and subophitic textures. The mineral assemblage includes clinopyroxene and subhedral plagioclase. In some cases the plagioclase is partially to completely transformed to sericite. Ilmenite, magnetite, titanite and zircon are present in small amounts, less than $5 \%$ of the mode. Chlorite, actinolite, epidote and prehnite are considered as secondary phases (Figure 1c). Chlorite presents uniform distribution in the diabases (BE.43, ED.110, KIL.2), filling up the interstices of the subophitic texture (Figure 1c). The metamorphic gabbro consists mainly of clinopyroxene (Figure 1d) and presents high percentage of chlorite. The chlorite displays large crystals which are unevenly distributed in the structure of the studied sample. Primary textures have been obliterated by deformation.

The studied intermediate-acidic volcanic samples comprise dacite (GE.22, GE.23) and andesite (BE.81, BE.82 and BE.101) with variable degrees of alteration. The dacite shows porphyritic texture and is dominated by quartz, plagioclase (partially to completely transform to sericite), hornblende, biotite and sanidine. Dacites also present extended transgranular microcracks. The andesite has porhyritic texture and is characterized mainly by the presence of mostly tabular sanidine phenocrysts. It is rich in clinopyroxene and biotite phenocrysts set in a glassy to microcrystalline groundmass of fluidal texture (Figure 1f). Plagioclase phenocrysts occur in all samples and are strongly zoned showing normal and oscillatory reverse zoning and they have been transformed partially to completely to sericite. Biotite is ubiquitous, showing intensive pleochroism in the shade of straw yellow to dark brown-reddish. Common accessory minerals include apatite, titanite, zircon and magnetite. 

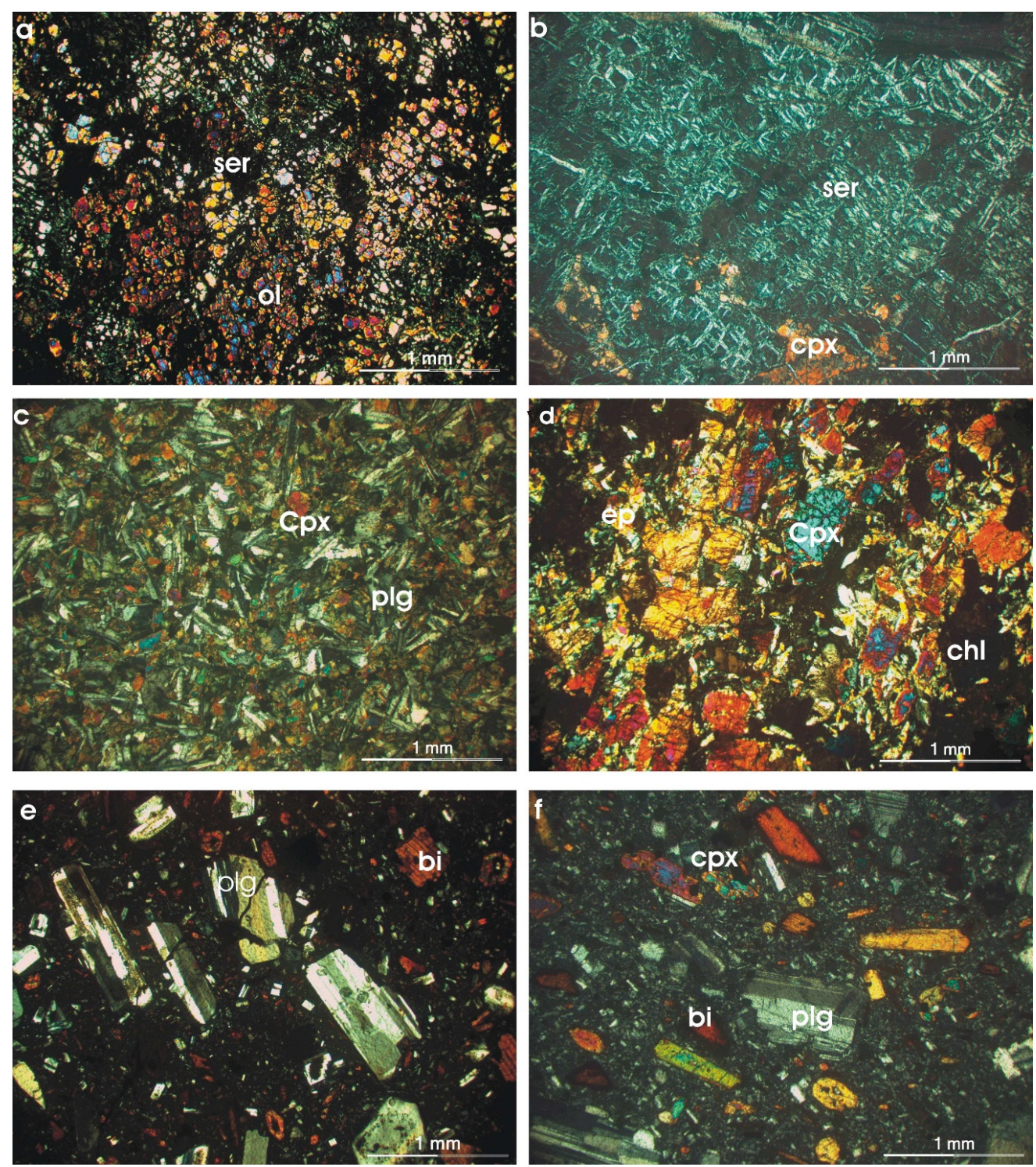

Figure 1. Photomicrographs of representative samples from the investigated rocks showing: (a) Granular and cataclastic texture in a serpentinized dunite (sample GE.37, XPL); (b) Mesh texture in a serpentinized lherzolite (sample BE.103, XPL); (c) Diabase showing subophitic texture with clinopyroxene and plagioclase crystals (sample KIL.2); (d) Metamorphic gabbro where clinopyroxene has been altered to epidote and chlorite (sample ED.26, XPL); (e) Dacite showing porphyritic texture with phenocrysts of plagioclase and biotite as well as transgranular microcracks (sample GE.22, XPL); (f) Andesite showing porphyritic texture with phenocrysts of plagioclase, biotite and clinopyroxene (sample BE.81, XPL); ep: epidote, cpx: clinopyroxene, chl: chlorite, ser: serpentine, plg: plagioclase, bi: biotite, ol: olivine.

\subsection{X-ray Diffraction and Quantitative Analysis of Aggregates}

Representative XRD patterns of bulk samples from the studied lithologies are shown in Figure 2. The XRD patterns of random powder mounts from the studied ultramafic rocks revealed that serpentine is the main alteration product in all samples (Table 1). In serpentinized dunite (GE.37), olivine, orthopyroxene, spinel and traces of magnetite and talc are also present in full accordance with the petrographic studies. In serpentinized harzburgite samples (ED.59, ED.115), serpentine is abundant; magnetite and spinel appear as minor mineral phases. Chlorite is also present in sample ED.59 and 
clinopyroxene in ED.115. In serpentinized lherzolite samples (BE.103, GE.42) serpentine is the main phase, clinopyroxene, garnet and spinel are present. Traces of chlorite are also present in sample GE.42.

In the studied mafic rocks the XRD patterns of the diabase samples (BE.43, ED.110, KIL.2, ED.24, and KIL.3) revealed the presence of clinopyroxene, plagioclase, chlorite, and actinolite in all samples. Quartz, titanite, and epidote are also present. Traces of magnetite and apatite are found in sample BE.43. The metamorphic gabbro consists mainly of clinopyroxene, chlorite, epidote, and prehnite (Table 2). Pumpellyite, titanite and ilmenite are also present in the metamorphic gabbro (ED.26).

The XRD patterns of the volcanic rocks showed that dacite samples (GE.22, GE.23) comprise quartz, plagioclase, biotite and K-feldspar. Cristobalite and traces of smectite are also present. In the andesite samples (BE.81, BE.82 and BE.101) plagioclase, K-feldspar, biotite and clinopyroxene are the main phases in full accordance with the petrographic studies. Traces of smectite are also present.
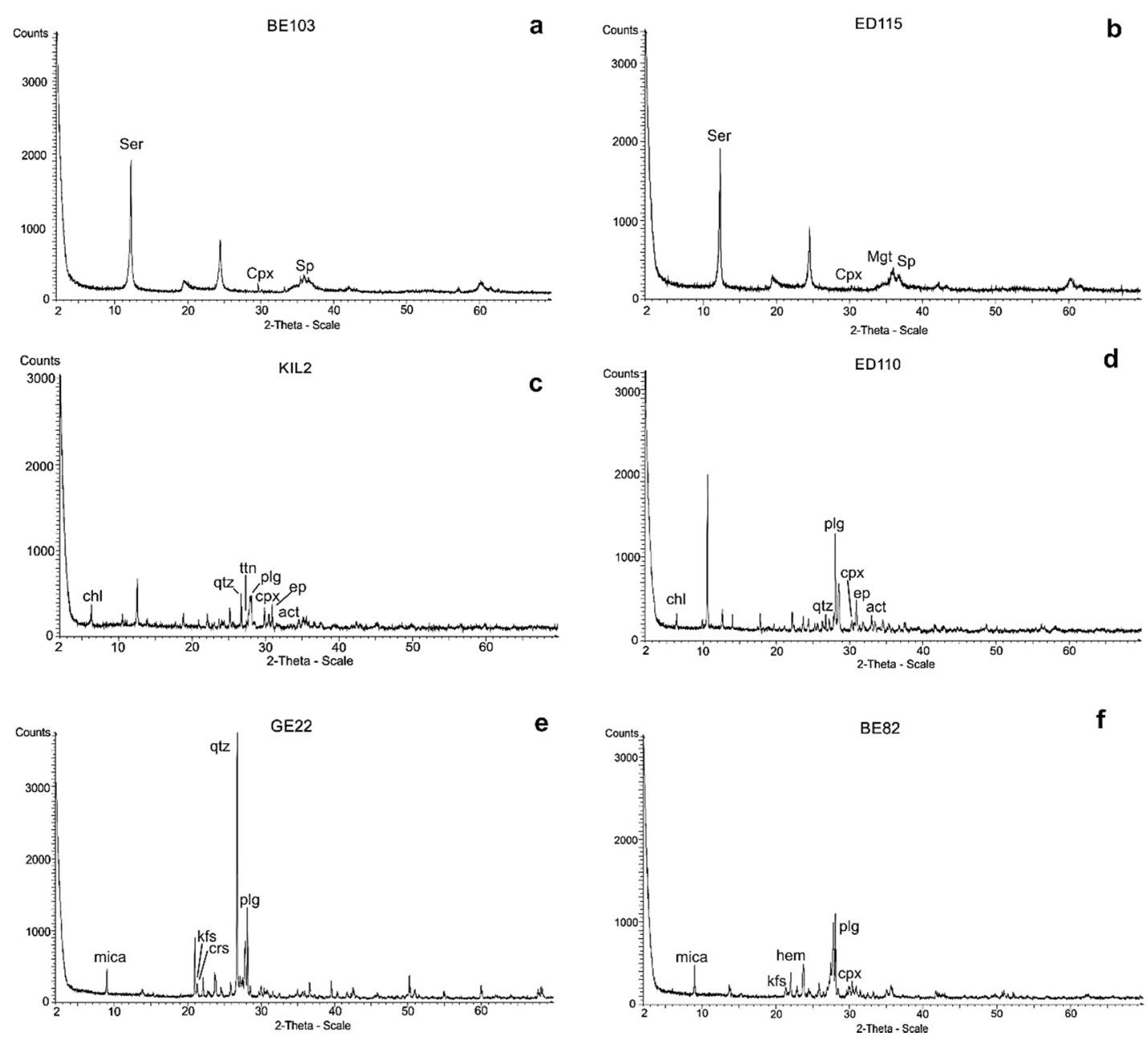

Figure 2. X-ray diffraction patterns of representative aggregate rocks: (a) Lherzolite (sample BE.103); (b) Harzburgite (sample ED.115); (c) Diabase (sample KIL.2); (d) Diabase (sample ED.110); (e) Dacite (sample GE.22); (f) Andesite (sample BE.82); Ser: serpentine, Cpx: clinopyroxene, Sp: spinel, Mgt: magnetite, Qtz: quartz, Ep: epidote, Chl: chlorite, Ttn: titanite, Act: actinolite, Plg: plagioclase, Kfs: K-feldspars, Crs: cristobalite, Mica: mica, Hem: hematite.

Representative X-ray diffraction patterns of the clay fraction from all rock-types are illustrated in Figure 3. The clay fraction of the serpentinized peridotites is dominated by serpentine and locally talc. Chlorite was also present in the serpentinized harzburgites. The clay fraction of the low grade metamorphism gabbro consists mainly of chlorite. Smectite and illite were identified in andesites and dacites. Serpentine and talc are identified by the characteristic reflections at $7.3 \AA$ and $9.3 \AA$ respectively, 
which are not affected upon ethylene glycol treatment. Chlorite shows the characteristic reflections at $14.2 \AA, 7.1 \AA$ and $3.55 \AA$, which remain unaffected after ethylene glycol treatment. Illite is identified by the reflections at $10 \AA, 4.97 \AA, 4.48 \AA$ and $3.3 \AA$. Smectite is identified by the characteristic reflection at $15.4 \AA$ and at $17 \AA$ after ethylene glycol treatment which shifts to $10 \AA$ after heating.

In the ultramafic rock samples the dominant secondary mineral is serpentine (Table 1) and only in two of the studied samples was secondary chlorite detected (Samples ED.59 and GE42). In the studied mafic rock samples the dominant secondary mineral is chlorite in the volcanic rock samples smectite is the dominant secondary mineral. As can be seen from Table 1 and the XRD patterns from the clay fraction, sample BE.82 (andesite) contains 2.8\% smectite, in contrast to sample BE.101 (dacite) which contains only $0.4 \%$ smectite (Table 1 , Figure 3 ).
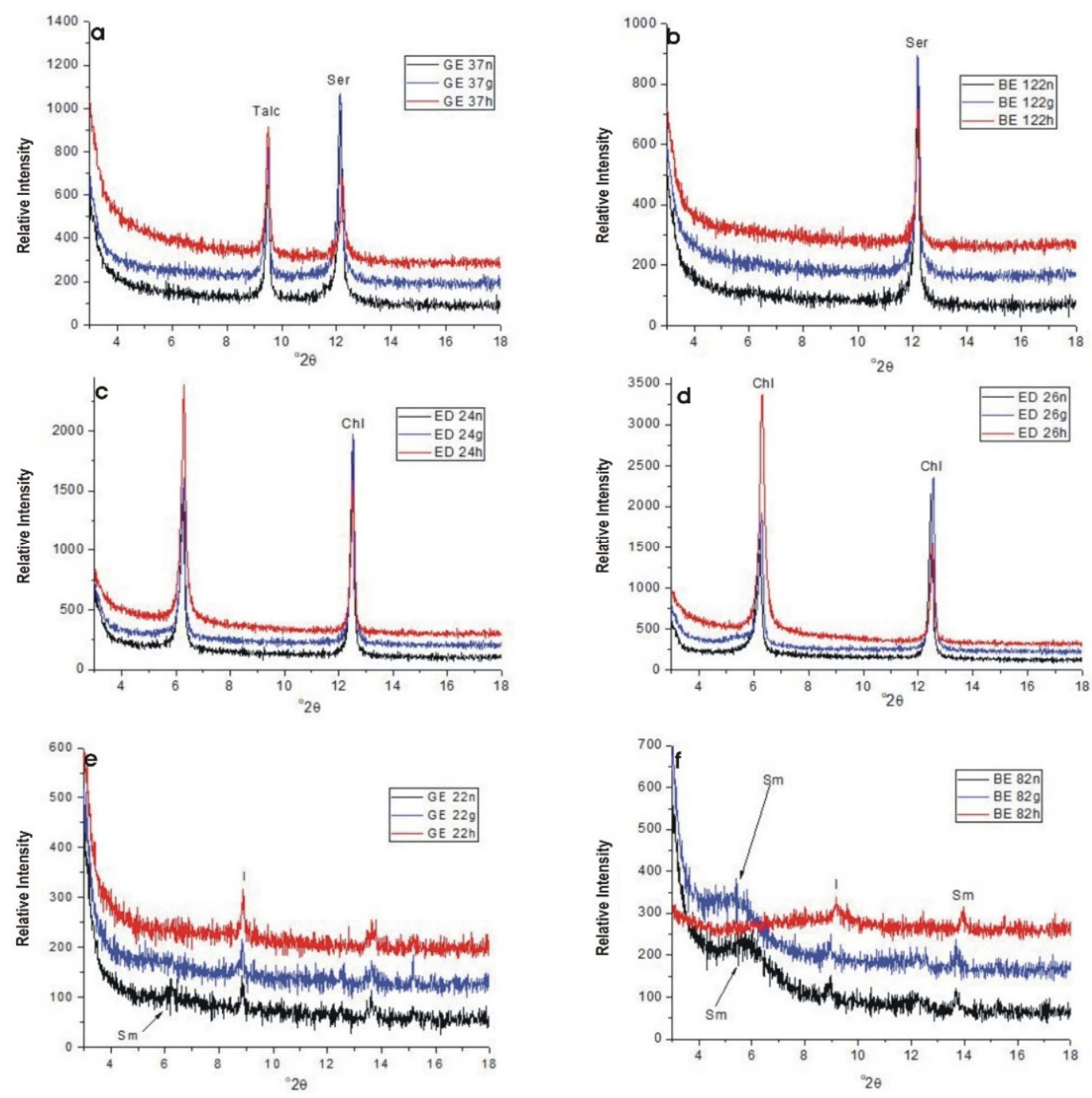

Figure 3. X-ray diffraction patterns of the clay fraction of representative studied samples: (a) Dunite (sample GE.37); (b) Serpentinized harzburgite (sample BE.122); (c) Diabase (sample ED.24); (d) Metamorphic gabbro (sample ED.26); (e) Dacite (sample GE.22); (f) Andesite (sample BE.82); sample numbers are given in the inserts; n: air-dried, g: glycolated, h: heated, Sm: smectite, I: illite, Ser: serpentine, Talc: talc, Chl: chlorite.

The quantification results of the mineralogical composition from the studied aggregate rocks, by the Rietveld refinement method in the bulk XRD patterns, are presented in Table 1 . The obtained compositions are consistent with the petrographic observations under the polarizing microscope. 
Table 1. Mineralogical composition of the studied rock samples (-: not detected). The quantification errors of $2-3$ wt $\%$ calculated for each phase according to Bish and Post [43,44].

\begin{tabular}{|c|c|c|c|c|c|c|c|c|c|c|c|c|c|c|c|c|}
\hline & \multicolumn{5}{|c|}{ Ultramafic Rocks } & \multicolumn{6}{|c|}{ Mafic Rocks } & \multicolumn{5}{|c|}{ Volcanic Rocks } \\
\hline & 1 & 2 & 3 & 4 & 5 & 6 & 7 & 8 & 9 & 10 & 11 & 12 & 13 & 14 & 15 & 16 \\
\hline Samples & BE.103 & GE.37 & ED.59 & ED.115 & GE.42 & BE.43 & ED.26 & ED.24 & ED.110 & KIL.2 & KIL.3 & BE.82 & GE.22 & GE.23 & BE.81 & BE.101 \\
\hline $\mathrm{Ol}$ & - & 43.7 & - & - & - & - & - & - & - & - & - & - & - & - & - & - \\
\hline Opx & - & 3.9 & - & - & - & - & - & - & - & - & - & - & - & - & - & - \\
\hline Cpx & 5.1 & - & - & 1.1 & 5.5 & 6.6 & 26.5 & 27.0 & 3.1 & 25.9 & 19.4 & 7.6 & - & - & 8.7 & 5.9 \\
\hline Sp & 6.5 & 6.3 & 5.3 & 7.1 & 5.0 & - & - & - & - & - & - & - & - & - & - & - \\
\hline Qtz & - & - & - & - & - & 6.0 & - & - & 2.1 & 5.1 & 4.2 & - & 30.5 & 15.8 & - & - \\
\hline Plg & - & - & - & - & - & 46.5 & 2.0 & - & 46.0 & 39.9 & 51.1 & 52.8 & 31.0 & 45.7 & 55.1 & 56.2 \\
\hline Kfs & - & - & - & - & - & - & - & - & - & - & 1.3 & 25.2 & 30.5 & 19.4 & 25.1 & 30.1 \\
\hline $\mathrm{Bi}$ & - & - & - & - & - & - & - & - & - & - & - & 5.6 & 2.1 & 9.4 & 6.1 & 2.4 \\
\hline Ttn & - & - & - & - & - & 2.5 & 4.1 & 2.5 & - & 1.7 & 0.9 & - & - & - & - & - \\
\hline $\mathrm{Ilm}$ & - & - & - & - & - & - & 2.0 & - & - & - & - & - & - & - & - & - \\
\hline Mgt & - & 4.6 & 5.7 & 3.2 & - & 4.0 & - & - & - & - & - & - & - & - & - & - \\
\hline Hem & - & - & - & - & - & - & - & - & - & - & - & 2.0 & - & - & 1.0 & 1.1 \\
\hline Ap & - & - & - & - & - & 2.4 & - & - & - & - & - & - & - & - & - & - \\
\hline Crs & - & - & - & - & - & - & - & - & - & - & - & - & 2.0 & 4.8 & - & - \\
\hline Ser & 87.0 & 35.0 & 84.0 & 88.6 & 83.0 & - & - & - & - & - & - & - & - & - & - & - \\
\hline Chl & - & - & 5.0 & - & 4.0 & 10.0 & 25.0 & 23.0 & 7.2 & 9.6 & 7.2 & - & - & - & - & - \\
\hline Act & - & - & - & - & - & 15.0 & - & - & 33.2 & 6.8 & 9.4 & - & - & - & - & - \\
\hline Ep & - & - & & - & - & 6.5 & 21.8 & 27.5 & 8.4 & 11.0 & 6.5 & - & - & - & - & - \\
\hline Talc & - & 6.5 & - & - & - & - & - & - & - & - & - & - & - & - & - & - \\
\hline Prh & - & - & - & - & - & - & 8.3 & 20.0 & - & - & - & - & - & - & - & - \\
\hline Pmp & - & - & - & - & - & - & 10.3 & - & - & - & - & - & - & - & - & - \\
\hline Grt & 1.4 & - & - & - & 2.5 & - & - & - & - & - & - & - & - & - & - & - \\
\hline Il & - & - & - & - & - & - & - & - & - & - & - & 3.8 & 2.5 & 4.2 & 3.1 & 3.9 \\
\hline $\mathrm{Sm}$ & - & - & - & - & - & - & - & - & - & - & - & 2.8 & 1.4 & 0.7 & 0.9 & 0.4 \\
\hline
\end{tabular}

Ol: olivine, Opx: orthopyroxene, Cpx: clinopyroxene, Sp: spinel, Qtz: quartz, Plg: plagioclase, Kfs: K-feldspars, Bi: biotite, Ttn: titanite, Ilm: ilmenite, Mgt: magnetite, Hem: hematite, Ap: apatite, Crs: cristobalite, Ser: serpentine, Chl: chlorite, Act: actinolite, Ep: epidote, Talc: talc, Prh: prehnite, Pmp: pumpellyite, Grt: garnet, Il: Illite, Sm: smectite. 
Table 2. Physical and mechanical properties of the tested samples and their minimum, maximum, and mean values as well as their petrographic indexes

\begin{tabular}{|c|c|c|c|c|c|c|c|c|c|c|}
\hline & & Samples & Lithology & Location & $w(\%)$ & $n_{t}(\%)$ & $L A(\%)$ & UCS (MPa) & Petrographic Index Values (\%) & Name of Index \\
\hline \multirow{8}{*}{ Ultramafic rocks } & 1 & BE.103 & Serp. Lherzolite & Veria-Naousa & 1.94 & 4.99 & 28.97 & 32.00 & 88.60 & \multirow{5}{*}{$U_{p h}$} \\
\hline & 2 & GE.37 & Serp. Dunite & Gerania & 0.43 & 0.76 & 17.36 & 100.00 & 41.50 & \\
\hline & 3 & ED.59 & Serp. Harzburgite & Veria-Naousa & 1.52 & 6.29 & 40.36 & 20.00 & 89.00 & \\
\hline & 4 & ED.115 & Serp. Harzburgite & Edessa & 2.10 & 4.53 & 20.77 & 28.00 & 87.00 & \\
\hline & 5 & GE.42 & Serp. Lherzolite & Gerania & 1.60 & 4.00 & 25.62 & 38.00 & 87.00 & \\
\hline & & & Mean & & 1.52 & 4.11 & 26.62 & 42.20 & 78.62 & \\
\hline & & & Minimum value & & 0.43 & 0.76 & 40.36 & 20.00 & 41.50 & \\
\hline & & & Maximum value & & 2.10 & 6.29 & 17.36 & 100.00 & 89.00 & \\
\hline \multirow{9}{*}{ Mafic rocks } & 6 & BE.43 & Diabase & Veria-Naousa & 0.25 & 0.53 & 8.72 & 150.00 & 10.00 & \multirow{6}{*}{$M_{p h}$} \\
\hline & 7 & ED.26 & Met. Gabbro & Edessa & 0.60 & 1.74 & 20.68 & 65.00 & 25.00 & \\
\hline & 8 & ED.24 & Diabase & Edessa & 0.52 & 0.84 & 14.15 & 91.33 & 23.00 & \\
\hline & 9 & ED.110 & Diabase & Edessa & 0.20 & 0.86 & 7.31 & 148.00 & 7.20 & \\
\hline & 10 & KIL.2 & Diabase & Guevgueli & 0.20 & 0.66 & 9.31 & 122.34 & 9.60 & \\
\hline & 11 & KIL.3 & Diabase & Guevgueli & 0.14 & 0.48 & 10.77 & 126.72 & 7.20 & \\
\hline & & & Mean & & 0.32 & 0.85 & 11.83 & 117.23 & 13.67 & \\
\hline & & & Minimum value & & 0.14 & 0.48 & 20.69 & 65.00 & 7.20 & \\
\hline & & & Maximum value & & 0.60 & 1.74 & 7.31 & 150.00 & 25.00 & \\
\hline \multirow{8}{*}{ Intermediate-acidic volcanic rocks } & 12 & BE. 81 & Andesite & Veria & 0.90 & 10.15 & 23.98 & 45.00 & 4.00 & \multirow{5}{*}{$V_{p h}$} \\
\hline & 13 & BE. 82 & Andesite & Veria & 1.14 & 10.76 & 35.00 & 35.62 & 6.60 & \\
\hline & 14 & BE.101 & Andesite & Veria & 1.70 & 11.62 & 55.00 & 37.47 & 4.30 & \\
\hline & 15 & GE.22 & Dacite & Ag. Theodori & 1.47 & 11.93 & 58.04 & 25.00 & 3.90 & \\
\hline & 16 & GE.23 & Dacite & Ag. Theodori & 2.13 & 8.40 & 50.62 & 33.11 & 4.90 & \\
\hline & & & Mean & & 1.47 & 10.57 & 44.53 & 35.24 & 4.74 & \\
\hline & & & Minimum value & & 0.90 & 8.40 & 58.04 & 25.00 & 3.90 & \\
\hline & & & Maximum value & & 2.13 & 11.93 & 23.98 & 37.47 & 6.60 & \\
\hline
\end{tabular}

$w=$ moisture content, $n_{t}=$ total porosity, $L A=$ Los Angeles test, $U C S=$ uniaxial compressive strength; Serp. = serpentinized; Met. = metamorphic. 


\subsection{Scanning Electron Microscopy}

\subsubsection{Surface Texture of the Studied Aggregates}

Surface texture is an expression of the microroughness of aggregate particles, and mainly depends on the petrographic features of rocks. The surface textures of the aggregate particles were studied using SEI. Differences in microroughness are apparent between different lithotypes (ultramafic, mafic and intermediate-acidic volcanic rock samples). As shown in Figure 4a, ultramafic rock samples with moderate alteration degree display rough microroughness while ultramafic rocks with intense alteration degree are characterized by smooth and glassy surface textures (Figure $4 \mathrm{~b}$ ). Regarding the mafic rock samples, those which contain low percentage of secondary minerals like KIL.2 (Figure 4c), present higher microtopography due to the presence of minerals of different hardness resulting in the development of rugged and irregular surfaces, than the more altered mafic rock samples (Figure 4d) which display smoother surface textures. As for the intermediate-acidic volcanic rocks, rough (Figure 4e) as well as smoother and glassier surface textures (Figure 4f) are observed relative to their alteration degree.
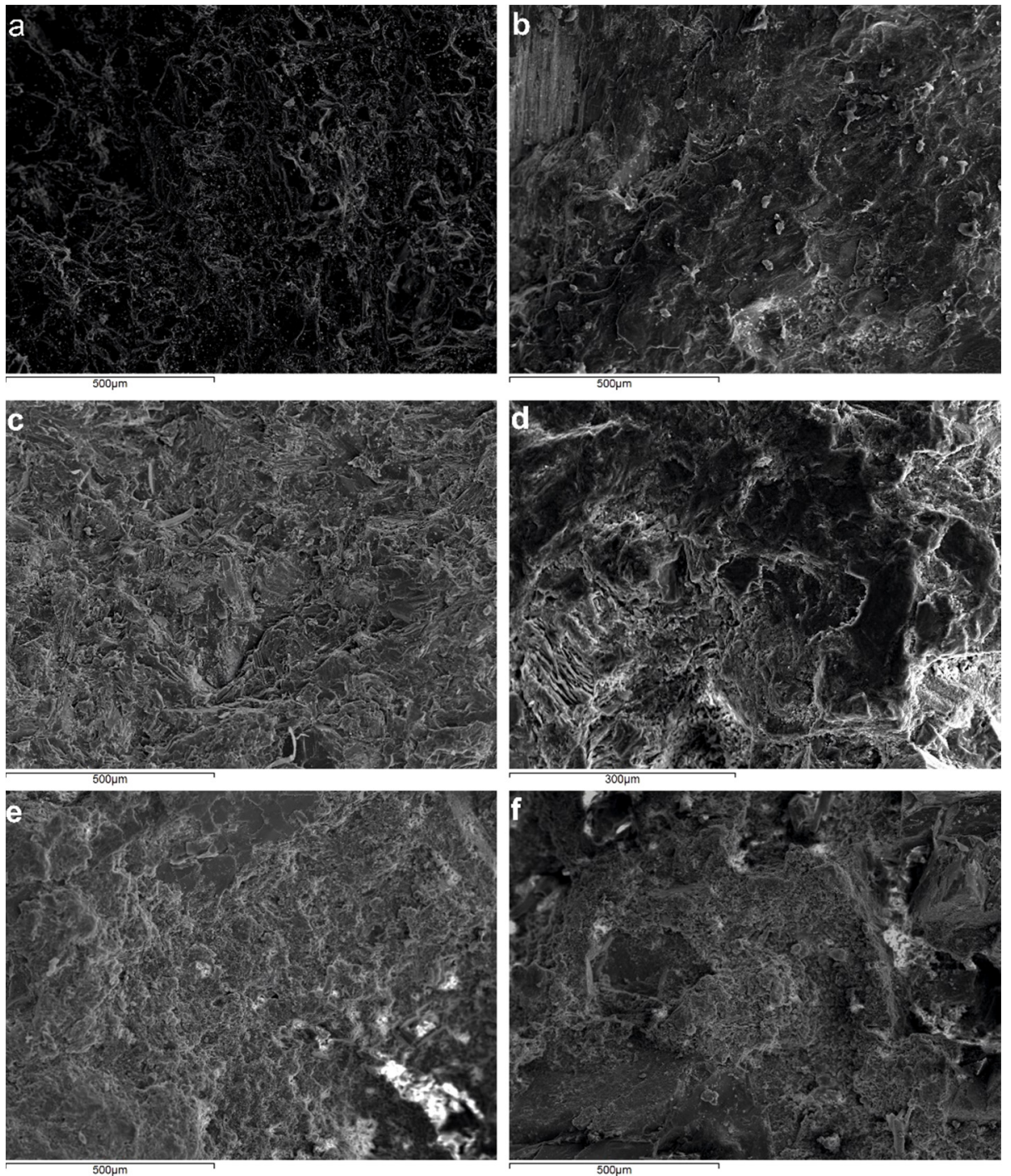

Figure 4. Secondary electron images (SEI) showing the surface texture of representative studied rocks. Differences in the mineralogical and textural features are also observed: (a) serpentinized Lherzolite (sample BE.103); (b) serpentinized Lherzolite (sample GE.42); (c) diabase (sample KIL.2); (d) metamorphic Gabbro (sample ED.26); (e) andesite (sample BE.101); (f) dacite (sample GE.23). 


\subsubsection{SEM Study of Clay Minerals}

The crystal morphology of the clay minerals was examined by SEM. The study revealed the occurrence of smectite flakes (Figure 5a-d), showing the typical smectite morphology, only in the intermediate-acidic volcanic samples (BE.101, GE.23). The observed smectite flakes were formed as a result of the partial alteration of plagioclase surfaces (Figure $5 c, d$ ). The limited alteration that was observed is in agreement with the low amount of smectite. It should be noted that a number of EDS analyses were performed on the surfaces of the samples but the results cannot be conclusive due to the small size of the smectite flakes and the low amount of smectite (the analyses were not only from smectite but also from the surrounding minerals).

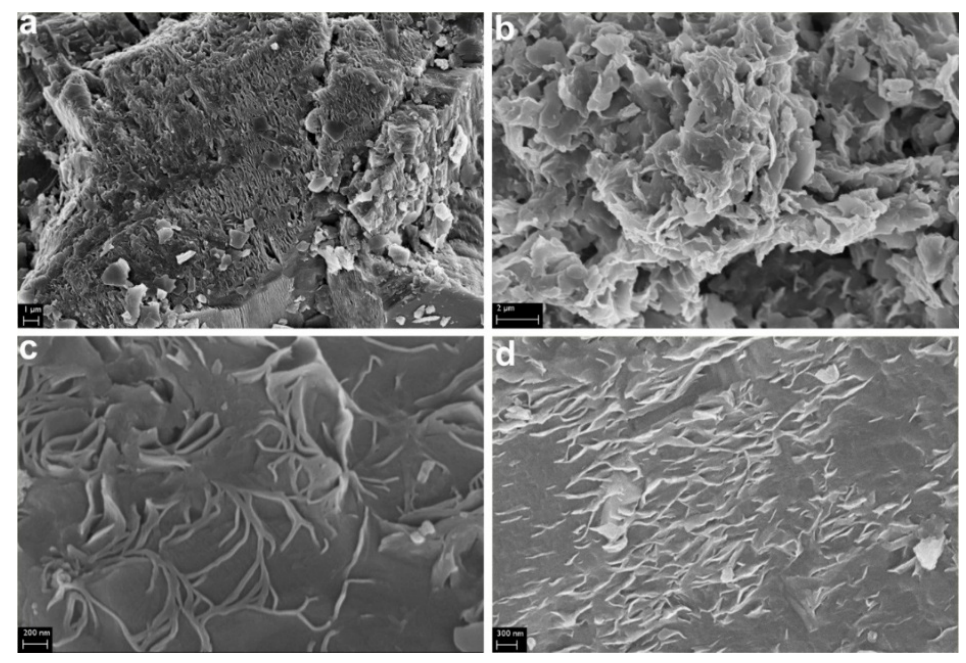

Figure 5. (a,c) SEI images of smectite flakes on plagioclase surfaces of andesite (sample BE.101); (b,d) SEI images with characteristic smectite flakes on plagioclase crystals of dacite (sample GE.23).

\subsection{Physicomechanical Properties of Aggregates}

The moisture content, the total porosity, the Los Angeles abrasion value and the uniaxial compressive strength of the studied aggregate rocks were determined. As shown in the table below (Table 2), the moisture content ranges between $0.20 \%$ and $2.13 \%$, with dacite (GE.23) having the highest value. The total porosity ranges between $0.48 \%$ and $11.93 \%$, with dacite (GE.22) having the highest value. Concerning the Los Angeles abrasion test, the resistance in abrasion of the studied rocks ranges between $7.31 \%$ and $58.04 \%$, with the diabase (ED.110) presented as the most resistant in abrasion compared to the altered dacite which is the less resistant aggregate. The uniaxial compressive strength of the tested rocks (average from six specimens) ranges between $20 \mathrm{MPa}$ and $148 \mathrm{MPa}$, where the most serpentinized harzburgite (ED.59) presents the lower strength and a lightly altered diabase is the most durable aggregate rock (ED.110).

\section{Discussion}

The ocean-floor metamorphism variably affected the collected ultramafic and mafic samples. During this process primary minerals from ultramafic and mafic rocks are often transformed to secondary ones as a result of the ocean-floor metamorphism process. This process is usually accompanied by a variable degree of metamorphism depending on the parent rock and the general context (i.e., pressure, temperature, hydrological features) of its formation. As a result, primary mineral assemblages are usually replaced by secondary hydrated minerals such as serpentine, amphibole, and chlorite as reported for the ultramafic and mafic rocks of the present study. In volcanic settings, the mineral composition and porous structure of the primary rocks can be intensively altered by various processes (i.e., hydrothermal), resulting in changes of their physical and mechanical properties. 
Moreover, weathering in volcanic samples is the commonest alteration cause. During the weathering of the investigated volcanic samples $\mathrm{Ca}, \mathrm{Mg}, \mathrm{K}, \mathrm{Na}, \mathrm{Rb}$, and $\mathrm{Sr}$ generally show a rapid, early loss which can be correlated with the alteration of volcanic glass to smectite and illite. Based on the results of this study, the understanding of the phyllosilicate secondary minerals behavior is of great importance in order to diagnose plausible problems in engineering constructions.

Regression analysis is the commonest statistical method for the investigation of the interdependence of the physical and mechanical parameters. Mechanical parameters such as UCS reduce as the porosity increases, while mechanical properties decrease as the alteration degree of rocks used as aggregates increases. Sabatakakis et al. [68] and Diamantis et al. [14] suggested correlations between UCS and porosity for several lithotypes studied. In this study, strong correlations were observed between the physical and mechanical properties. As can be seen from Figure 6 the LA (\%) and UCS (MPa) values of the rocks are influenced by their total porosity $n_{t}(\%)$ and the moisture content $w(\%)$. The logarithmic equation (UCS $=-34.44 \ln \left(n_{t}\right)+103.61, R^{2}=0.82$ ) seems to better fit UCS with porosity (Figure 6a) presenting similar trends with Undul [16], while the relationship between the Los Angeles abrasion value and porosity (Figure $6 c$ ) can be better described by the linear equation $\left(L A=3.3336 n_{t}+10.303, R^{2}=0.76\right.$ ). Moreover, there is a moderate correlation between the uniaxial compressive strength and the moisture content with a clear trend between these two properties (Figure $6 \mathrm{~d}$ ) and good correlation between the Los Angeles and the moisture content as shown in Figure $6 \mathrm{~b}$, expressed by the exponential equation $L A=9.9902 \mathrm{e}^{0.7445 \mathrm{w}}, R^{2}=0.65$. The best relationship is found between moisture content and uniaxial compressive strength determined by a logarithmic equation $\left(U C S=-46.93 \ln (w)+55.141, R^{2}=0.90\right)$. These relationships (Figure 6) verify the hypothesis of many researchers for the interdependence between the physical and mechanical parameters. This is probably due to the fact that the minerals which have the ability to retain water in their structure may create more surfaces of weakness in the rocks resulting in their lower mechanical performance in contrast to rocks which contain minerals unable to retain water in their structure. These rocks are presented as more resistant under mechanical stress. In the studied samples a wide range in the mechanical properties of the rocks was observed (Table 2). This could be due to the internal discontinuities, as a result of the different degrees of alteration due to the formation of secondary phyllosilicate minerals which are able to retain water in their structure. Thus, knowledge of the presence and type of the secondary phyllosilicate minerals seems to be a determinant factor for the investigation of the physical and mechanical properties.
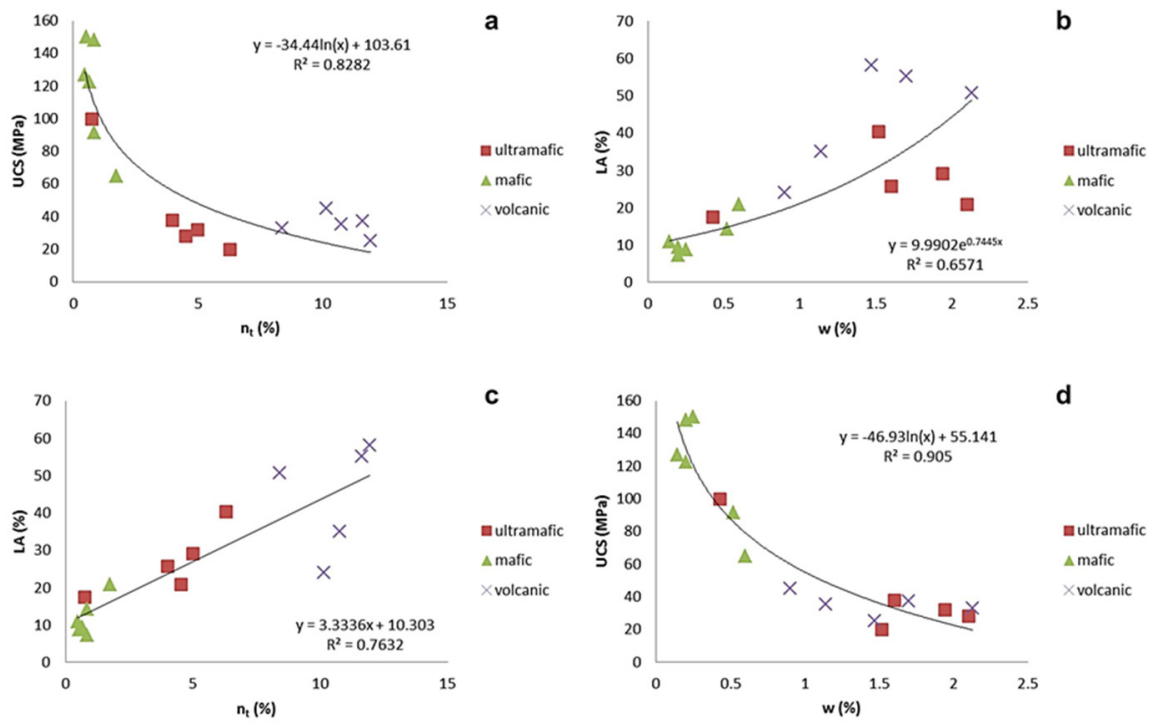

Figure 6. (a) The uniaxial compressive strength values (UCS (MPa)) versus the total porosity $\left(n_{t}(\%)\right)$ of the studied rocks; (b) the Los Angeles abrasion values $(L A(\%))$ versus the moisture content $(w(\%))$ of the studied rocks; (c) $L A(\%)$ versus $n_{t}(\%)$ of the studied rocks; (d) the uniaxial compressive strength values (UCS (MPa)) versus the moisture content $(w(\%))$ of the studied rocks. 


\subsection{The Impact of Secondary Phyllosilicate Minerals on Engineering Properties of Ultramafic Rocks}

The studied ultramafic rocks derived from three ophiolite complexes in Greece were variably affected by serpentinization as it can be seen in Table 1 and described in Section 4.1 (Figure 1a,b). The primary minerals of the studied ultramafic rocks were converted to secondary mineral phases as a result of the ocean-floor metamorphism process. In order to present the effect of the secondary phyllosilicate minerals on the engineering properties of aggregates the $U_{p h}$ index is proposed for the ultramafic rocks and is used for the correlation analysis with engineering parameters. This petrographic index $U_{p h}(\%)$ is the sum of the secondary phyllosilicate minerals present in ultramafic rocks and can be described by the following equation:

$$
U_{p h}=\operatorname{Serp}(\%)+\operatorname{Chl}(\%)+\text { Talc }(\%),
$$

where Serp is serpentine and $\mathrm{Chl}$ is chlorite.

The sum of the phyllosilicate minerals $\left(U_{p h}\right.$ index), reflects the degree of alteration of the studied ultramafic rocks and may influence their physicomechanical properties. Regression analysis was applied among the petrographic data and the physicomechanical properties of the ultramafic samples in order to clarify the relationships between the secondary phyllosilicate minerals and the engineering properties. The petrographic index $U_{p h}$ displays significant correlations with the UCS and the total porosity of the aggregates (Figure 7). The $U_{p h}$ index shows positive logarithmic correlation with the porosity which can be described by the equation $n_{t}=0.1413 \mathrm{e}^{0.0403 U_{p h}}, R^{2}=0.97$ (Figure 7a).

The recommended relationships between the degree of alteration and the physicomechanical properties are similar to the results of Diamantis et al. [69] who studied peridotites from central Greece, as well as similar to the results of Undul and Tugrul [70] who studied dunites from northwestern Turkey. As is shown in Table 2, the sample GE.37 (serpentinized dunite) presents the minimum porosity value and the minimum value of moisture content, as well as the lower percentage of phyllosilicate minerals. The interdependence of $U_{p h}$ index with the physical properties of ultramafic aggregates is also supported by the fact that the sample ED.59 (serpentinized harzburgite) presents the maximum value of moisture content, going far beyond the mean value of the moisture content as well as presenting at the same time the highest $U_{p h}$ index.

The increasing ability of ultramafic rocks which contain high contents of phyllosilicate minerals such as serpentine, chlorite, talc, to incorporate water can be explained by the fact that these platy or tabular secondary minerals have the capability to adsorb water. These minerals usually form foliated masses which contribute to the development of more porous areas and they can also result from precipitation by hydrothermal fluids in fractures driven by tectonic regimes. The other minerals of ultramafic rocks (primary and secondary) do not have a similar effect on their physical properties maybe due to their crystal structure. The degree of alteration and the formation of secondary hydrated minerals combined with their structure may lead to various property changes. On the other hand, ultramafic rocks with low degree of alteration tend to have low porosity and permeability, massive crystalline structures as well as and generally having better physicomechanical performance.

On the other hand, an inverse relationship which can be described by the equation $U C S=-1.5656 U_{p h}+165.29,\left(R^{2}=0.97\right)$ was found between $U_{p h}$ and uniaxial compressive strength (Figure $7 \mathrm{~b}$ ) suggesting that these phyllosilicate minerals are the determinant factors among the other minerals influencing the mechanical performance of aggregates. Figure $7 \mathrm{a}, \mathrm{b}$ supports the interpretation mentioned above in Figure 6, because the phyllosilicate minerals, due to their platy and layered character, form foliated masses which lead to the development of larger pores and open surfaces which are responsible for mechanically weaker rocks as these areas disturb the cohesiveness of the rock's structure. As shown in Table 2, the effect of the amount of the secondary phyllosilicate minerals on the engineering properties of the studied ultramafic rock samples can be observed as sample GE.37 presents the minimum percentage of secondary phyllosilicate minerals $\left(U_{p h}\right)$ and also presents considerably better mechanical and physical performance (the lowest $w, n_{t}$, the lowest resistance 
in abrasion and the highest UCS value) in contrast to ED.59 which presents the worst mechanical performance among the studied ultramafic rocks, having the highest percentage of the secondary phyllosilicate minerals. However, we observed that the $L A$ values do not present an absolute relation with the percentage of the secondary phyllosilicate minerals ( $U_{p h}$ index). This fact which may occur happen due to a combination of petrographic parameters such as texture, the type of primary minerals and their relationship with the secondary minerals of the studied rocks. The secondary phyllosilicate minerals due to their low hardness in conjunction with their phyllosilicate structure have different microroughness. As can be seen in Figure 4, with decreasing alteration (i.e., decreasing contents of secondary phyllosilicate minerals) (Table 1) the surface of the particles has rough microroughness (Figure 4). This is explained by the platy and soft nature of phyllosilicate minerals and mainly by the serpentine structure. The low microtopography results in a considerable reduction of mechanical properties which hence influences the engineering constructions, because the smooth surfaces of the particles of ultramafic rocks, due to low microroughness, do not favor strong adherence with the cement paste in the concrete [11].
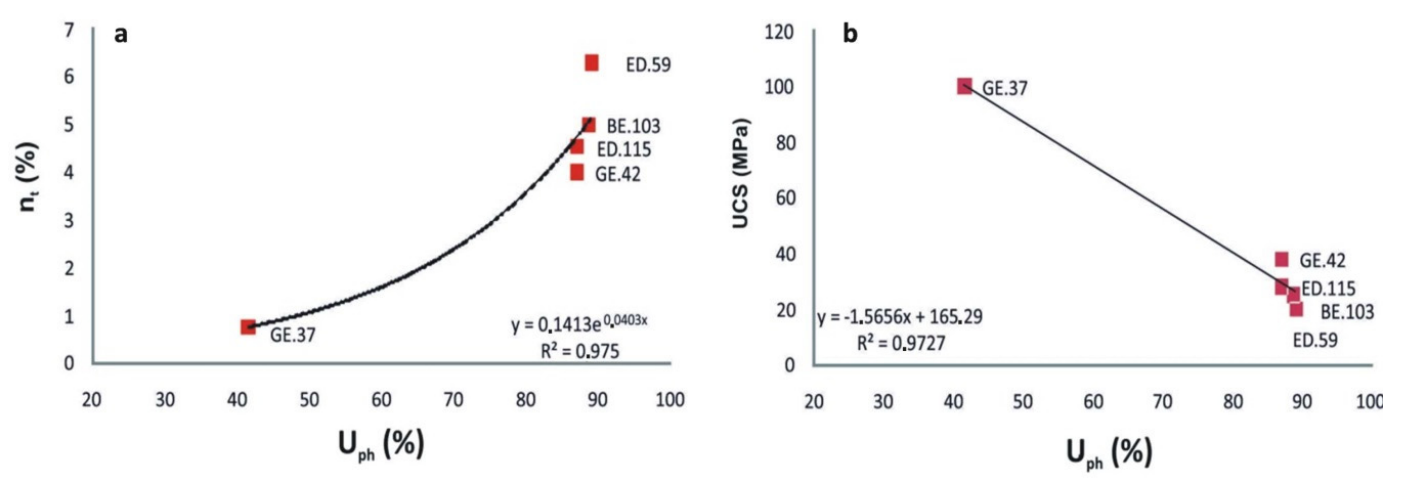

Figure 7. (a) The total porosity $\left(n_{t}(\%)\right)$ versus the petrographic index $\left(U_{p h}(\%)\right)$ of the studied ultramafic rocks; (b) the uniaxial compressive strength test (UCS (MPa)) versus the petrographic index $\left(U_{p h}(\%)\right)$ of the studied ultramafic rocks.

The statistical significance of these correlations was also evaluated using the $t$-test and the $p$-value, as they do not present normal distribution. The significantly higher absolute values of the $t$-test compared to the critical $t$-table values for confidence levels higher than the $90 \%$ (for the $U_{p h}$-UCS pair) and $95 \%$ (for the $U_{p h}-n_{t}$ pair), as well as the very low $p$-values of these pairs, strongly suggest the validity of their interrelationships (Table 3). This evidence strongly supports the hypothesis of the influence of the phyllosilicate secondary minerals on the engineering properties of the studied mafic rock samples.

Table 3. Paired $t$-test results for the statistical correlations of the indices $U_{p h}$ and UCS, $n_{t}$. The listed critical $t$-table values are for the relevant freedom degrees (dF) and for confidence levels of $99 \%$ $(a=0.01), 98 \%(a=0.02), 95 \%(a=0.05)$ and $90 \%(a=0.10)$.

\begin{tabular}{cccccccc}
\hline \multirow{2}{*}{ Pair } & \multirow{2}{*}{-Test } & \multirow{2}{*}{$\mathbf{d F}$} & $\boldsymbol{p}$-Value & \multicolumn{4}{c}{$\boldsymbol{t}$-Table Values } \\
\cline { 5 - 8 } & & & & $\boldsymbol{a}=\mathbf{0 . 0 1}$ & $\boldsymbol{a}=\mathbf{0 . 0 2}$ & $\boldsymbol{a}=\mathbf{0 . 0 5}$ & $\boldsymbol{a}=\mathbf{0 . 1 0}$ \\
\hline$U_{p h}(\%)-\mathrm{UCS}(\mathrm{MPa})$ & 1.5202 & 4 & 0.2030 & 3.7469 & 2.9985 & 2.1318 & 1.5332 \\
$U_{p h}(\%)-\mathrm{n}_{\mathrm{t}}(\%)$ & 8.8239 & 4 & 0.0009 & 3.7469 & 2.9985 & 2.1318 & 1.5332 \\
\hline
\end{tabular}

\subsection{The Impact of Secondary Phyllosilicate Minerals on Engineering Properties of Mafic Rocks}

The studied mafic rocks from three different ophiolite complexes of Greece include chlorite as the main phyllosilicate alteration product (Table 1, Figure 1). Chlorite primarily occurs as a hydrothermal alteration product of ferromagnesian minerals in igneous rocks and especially in mafic altered rocks. This case study focuses on the content of phyllosilicate minerals, as they seem to significantly influence 
the engineering performance of mafic rocks. Several scientists have attempted to assess the quality of mafic igneous rocks according to the micropetrographic indexes. Weinert [71] classified mafic rocks according to the total percentage of secondary minerals. In order to present the effect of the secondary phyllosilicate minerals on the engineering properties of aggregates, the $M_{p h}$ index was introduced in this paper, which is the sum of the phyllosilicate minerals. In this case study, only chlorite is present from the phyllosilicate secondary phases; therefore $M_{p h}$ can be described by the following equation:

$$
M_{p h}=\operatorname{Chl}(\%)
$$

Regression analysis was applied between the $M_{p h}$ index and the physicomechanical properties of the mafic rock samples. The moisture contents of the studied mafic samples show strong positive relationships which can be expressed by the equation $w=0.0235 M_{p h}-0.0024, R^{2}=0.98$ with the $M_{p h}$ suggesting the decisive role of chlorite on this engineering parameter of the aggregates (Figure 8a). Although the contribution of other secondary minerals (Table 1) in the total moisture content cannot be excluded, the strong positive correlation between $M_{p h}$ and $w(\%)$ suggests that chlorite is the main mineral phase that determines the moisture content in the studied mafic rocks. Moreover, a strong negative correlation expressed by the equation UCS $=186.18 \mathrm{e}^{-0.037 M_{p h}},\left(R^{2}=0.84\right)$ exists between $M_{p h}$ and UCS (Figure 8b). As shown in Table 2, the sample KIL.3 (diabase), presents at the same time minimum values in physical properties such as moisture content and total porosity and a minimum in $M_{p h}$ index. Moreover, the sample ED.26 (metamorphic gabbro) presents the highest percentage of phyllosilicate minerals $\left(M_{p h}\right.$ index) and the maximum values in physical properties and the Los Angeles property simultaneously.

The mechanical behavior of the studied mafic rocks can be better studied by the contribution of the petrographic methods employed in the present study. The content of secondary phyllosilicate minerals, described by the $M_{p h}$ index, in combination with the microtopography of some mafic samples compared to other mafic samples seems to control their mechanical behavior as aggregates. The combination of petrographic methods is able to interpret the best microtopography of some mafic samples in relation to other mafic samples as well as the best final mechanical behavior of them as aggregates. Samples with low percentage of chlorite (Table 1, sample ED.110), which is evenly distributed (Figure 1c), exhibit higher microroughness (Figure 4c) and better mechanical behavior (Table 2). On the other hand, samples with high percentage of chlorite which is unevenly distributed in the structure of the rock (Figure 1d), are observed to result in lower microroughness (Figure 4d) and inferior mechanical behavior (Table 2), as the extensive areas of chlorite probably create failure points in the material under mechanical stress (uniaxial compressive strength and Los Angeles abrasion) (Table 2). This can be better explained by the crystal structure of chlorite which is a hydrated phyllosilicate mineral. The ability of chlorite to adsorb and retain water in the layers of its structure (Figure 8a), decreases the uniaxial compressive strength of the host rock (Figure 8b), as the numerous layers can act as surfaces of weakness for the rocks.
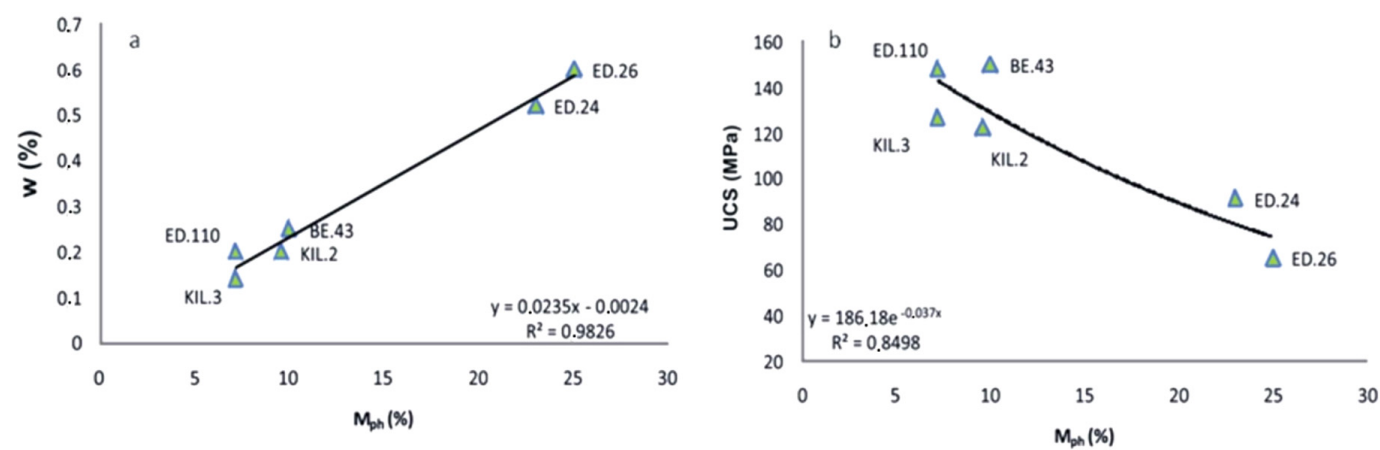

Figure 8. (a) The moisture content $(w(\%))$ versus the petrographic index $\left(M_{p h}(\%)\right)$ of the studied mafic rocks; (b) the uniaxial compressive strength test (UCS (MPa)) versus the petrographic index $\left(M_{p h}(\%)\right)$ of the studied mafic rocks. 
The statistical significance of the $R^{2}$ values is appraised again using the $t$-test and the $p$-value, as $w$ vs. $M_{p h}$ and UCS vs. $M_{p h}$ does not present normal distribution. The significantly higher absolute values of the $t$-test compared to the critical $t$-table values for confidence levels even higher than the $99 \%$, as well as the very low $p$-values of these pairs, strongly suggest the validity of these relationships (Table 4) supporting the hypothesis of the influence of the phyllosilicate secondary minerals on the engineering properties of the studied mafic rock samples.

Table 4. Paired $t$-test results for the statistical correlations of the indexes $M_{p h}$ and UCS and $w$. The listed critical $t$-table values are for the relevant freedom degrees $(\mathrm{dF})$ and for confidence levels of $99 \%(a=0.01)$, $98 \%(a=0.02), 95 \%(a=0.05)$ and $90 \%(a=0.10)$.

\begin{tabular}{cccccccc}
\hline \multirow{2}{*}{ Pair } & \multirow{2}{*}{-Test } & \multirow{2}{*}{$\mathbf{d F}$} & $\boldsymbol{p}$-Value & \multicolumn{4}{c}{$\boldsymbol{t}$-Table Values } \\
\cline { 5 - 8 } & & & & $\boldsymbol{a}=\mathbf{0 . 0 1}$ & $\boldsymbol{a}=\mathbf{0 . 0 2}$ & $\boldsymbol{a}=\mathbf{0 . 0 5}$ & $\boldsymbol{a}=\mathbf{0 . 1 0}$ \\
\hline$M_{p h}$-UCS (MPa) & -6.2133 & 5 & 0.0015 & 3.3649 & 2.7565 & 2.0150 & 1.4758 \\
$M_{p h}-w(\%)$ & 4.1265 & 5 & 0.0091 & 3.3649 & 2.7565 & 2.0150 & 1.4758 \\
\hline
\end{tabular}

\subsection{The Impact of Secondary Phyllosilicate Minerals on Engineering Properties of Volcanic Rocks}

The studied intermediate-acidic volcanic rocks from Greece include smectite and illite as the main phyllosilicate alteration products. Weathering reactions mainly involve the transformation of feldspars from andesites and dacites to smectite and illite. This case study focuses on the content of secondary phyllosilicate minerals of volcanic rocks. In order to present the effect of the secondary phyllosilicate minerals on the engineering properties of aggregates, the $V_{p h}$ index was employed for the volcanic rocks. The $V_{p h}$ index is an expression of the sum of the secondary phyllosilicate minerals present and can be described by the following equation:

$$
V_{p h}=\operatorname{Sm}(\%)+\operatorname{Ill}(\%)
$$

where Sm is smectite and Ill is illite.

Many scientists have studied the behavior of these clay minerals in soils [72], while there are few who have studied the behavior of clay minerals in rocks, as this identification constitutes a quite difficult (especially for small amounts of clay minerals) and precarious process. Nevertheless, from an engineering point of view, the most complicated rocks in the construction industry are volcanic rocks containing swelling clay minerals. This may be due to the fact that even the low percentages of smectite and illite are capable of adsorbing water in their phyllosilicate structure (especially smectite) during the preparation of engineering constructions such as concretes. From these, the swelling clay minerals of smectite may swell up significantly [73] hence causing severe destruction to their host rocks. Another possible factor which may influence the physicomechanical performance of volcanic rocks may be the distribution of clay minerals. When clay minerals are clustered along continuous surfaces they may act as preferential sliding planes, while when they are dispersed, the bulk mechanical properties come from the network of primary minerals and glasses. Therefore the clay minerals could probably create preferential sliding planes easier in andesitic and dacitic rocks than in mafic and ultramafic rocks. Petrounias et al. [11] referred the percentage of smectite as a determinant factor as for $L A$ and as for UCS of the studied andesites, highlighting the detrimental effects of smectite on the performance of the host rocks. However, it should be mentioned that the samples studied by Petrounias et al. were andesites from only one area which are characterized by similar microtectonic stress and similar textural features. In this case study, it was attempted to highlight the effect of the total phyllosilicate minerals $\left(V_{p h}\right)$ on their physicomechanical properties from different areas. The statistical processing between the $V_{p h}$ index and the engineering tests of these rocks did not show up any clear correlation among the test variables (Figure 9a,b, Table 2). The studied samples of this case study, as shown in Figure 9, present no systematic correlation between the percentages of secondary phyllosilicate minerals ( $V_{p h}$ index) and their engineering properties. The absence of correlation of 
these parameters may occur due to the fact that the studied rock samples (andesites and dacites) are derived from two geologically different areas of Greece. The different tectonic evolution of the investigated areas combined with differences in the size of phenocrysts may constitute the main reasons for their physicomechanical performance. For example, while the sample BE.81 presents (Table 2) the highest mechanical performance (minimum $L A$ and maximum UCS values) and sample GE.22 presents the lowest mechanical performance (maximum $L A$ and minimum UCS values), nevertheless they both display minor differences in their $V_{p h}$ index. This probably occurs because dacites from the Agioi Theodori area contain phenocrysts of bigger size in contrast to andesites from Veria. Moreover, the fact that the area of Agioi Theodori presented as more tectonically stressed and spatially related to extensional faults at the margin of the Saronicos basin compared with the Veria area, affects differently the physicomechanical performance of the studied aggregates. It is obvious that the factors which influence the physicomechanical properties of volcanic rocks constitute a complex system where it is not possible to attribute it only to the content of samples in secondary phyllosilicate minerals and especially when these are below $7 \%$ of the total of the mineralogical composition of the tested volcanic rock samples. According to the above, it is clear that the $V_{p h}$ in these rocks should be avoided to be used as s index of impact on the engineering values mainly due to the different hydration and swelling properties of these clay minerals (smectite and illite) in combination with their very low content.
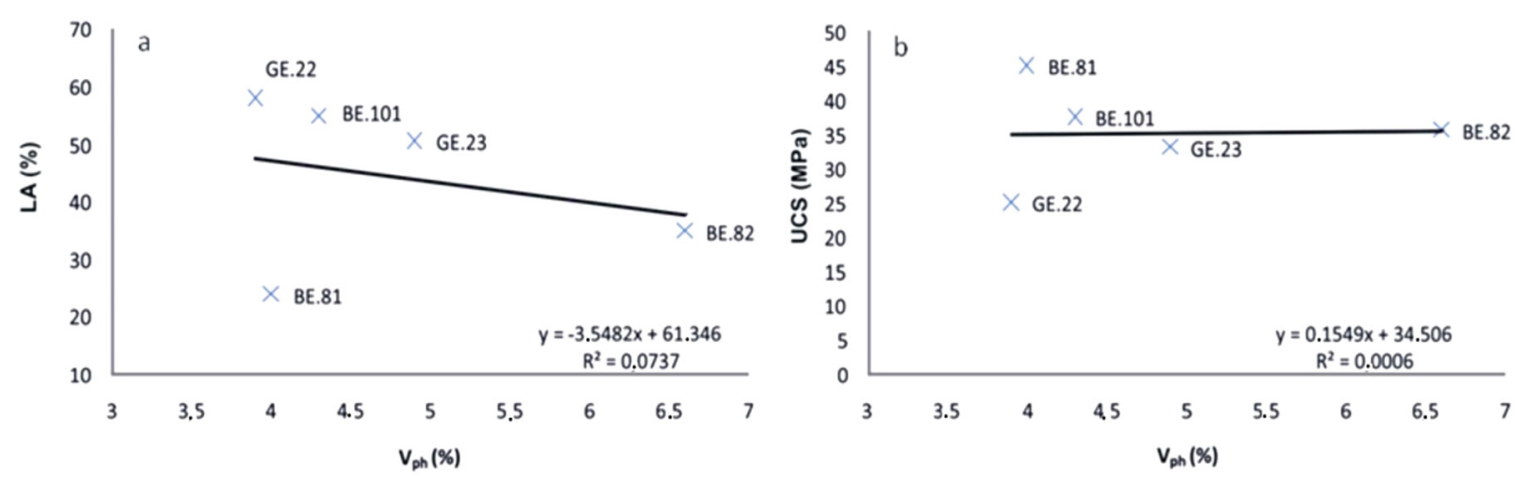

Figure 9. (a) The Los Angeles abrasion test $(L A(\%))$ versus the petrographic index $\left(V_{p h}(\%)\right)$ of the studied volcanic rocks; (b) the uniaxial compressive strength test (UCS (MPa)) versus the petrographic index $\left(V_{p h}(\%)\right)$ of the studied volcanic rocks.

\section{Conclusions}

This paper investigated the impact of the presence and type of secondary phyllosilicate minerals of ultramafic, mafic, and intermediate-acidic volcanic rocks with a variable degree of alteration on the engineering properties of these studied rocks when used as aggregates. The studied samples presented various percentages and types of secondary phyllosilicate minerals depending on their different parent rocks. For this purpose a combination of petrographic methods was employed and the physicomechanical properties of these various igneous rocks were studied. With the increasing percentage of secondary phyllosilicate minerals, the engineering properties of the ultramafic and mafic rocks were differentially aggravated. The increase of serpentine and chlorite content in ultramafic and mafic rock samples results in increasing their ability to adsorb and retain water in the layers of their structure, in the decreasing of their uniaxial compressive strength, as the numerous layers can act as surfaces of weakness for the rocks, and consequently in the development of low microroughness of these aggregates. Nevertheless the increasing percentage of phyllosilicate minerals in mafic rocks seems to influence strongly their resistance to abrasion, in contrast to ultramafic rocks where no systematic relationship was observed, as their resistance to abrasion depends on a combination of petrographic factors. On the other hand, the total percentage of secondary phyllosilicate minerals of the studied intermediate-acidic volcanic rocks, which contain minor amounts, does not seem to be a determinant factor influencing their engineering properties. 
This paper suggests three different petrographic indexes, one for each lithotype. The $U_{p h}$ index, expressing the sum of the secondary phyllosilicate minerals of the studied ultramafic rocks, may constitute a safe index to predict their physicomechanical properties and hence for the estimation of possible failures on various engineering constructions. As for the mafic rocks, the content of chlorite expressed by the $M_{p h}$ index is a safe index for the evaluation of the quality of mafic aggregates in various construction applications. The prediction of the physicomechanical performance of the studied intermediate-acidic volcanic rocks cannot be based on the $V_{p h}$ index, as it seems that a combination of factors (such as textural characteristics and size of phenocrysts) significantly contributes to the final mechanical strength of these rocks

The combination of petrographic methods with the engineering properties constitutes a useful tool for the evaluation of rocks as aggregates.

Author Contributions: P.P. participated in the fieldwork, the elaboration of laboratory tests, the interpretation of the results, coordinated the research and wrote the manuscript; P.P.G. participated in the fieldwork, the elaboration of laboratory tests, the interpretation of the results, and contributed to the manuscript writing; A.R. participated in the fieldwork, performed the SEM work, the interpretation of the results, and contributed to the manuscript writing; P.L. carried out the XRD analyses and participated in the interpretation of the results; E.K. participated in the elaboration of laboratory tests, the mineralogical analyses, and mineral quantification of the samples, the interpretation of the results, and contributed to the manuscript writing; D.P. participated in the elaboration of the mineralogical analyses of clay minerals and the interpretation of the results; B.T. participated in the fieldwork, the interpretation of the results, and the coordination of the research; and K.H. participated in the interpretation of the results and the coordination of the research.

Funding: This research received no external funding.

Acknowledgments: The authors wish to thank Drakopoulos of the Foundation for Research and Technology-Hellas (FORTH) Institute of Chemical Engineering and High Temperature Chemical Processes (ICE/HT) Rio-Patras, Greece and A.K Seferlis of the Laboratory of Electron Microscopy and Microanalysis, University of Patras for his assistance with the microanalyses and SEM micrographs. Critical reviews from three anonymous reviewers have substantially improved the manuscript and are gratefully acknowledged.

Conflicts of Interest: The authors declare no conflict of interest.

\section{References}

1. Langer, W.H. The Geologic Occurrence of Potential Sources of Crushed Stone and Sand and Gravel for Use as Natural Aggregate and a Summary of the Natural Aggregate Industry; U.S Geological Survey Bulletin 1594; Department of the Interior Donald Paul Hodel Washington: Washington, DC, USA, 1988.

2. Shakoor, A.; Bonelli, R.E. Relationship between petrographic characteristics, engineering index properties and mechanical properties of selected sandstones. Bull. Assoc. Eng. Geol. 1991, XXVII, 55-71. [CrossRef]

3. Haney, M.G.; Dhakoor, A. The relationship between tensile and compressive strengths for selected sandstones as influenced by index properties and petrographic characteristics. In Proceedings of the 7th International. IAEG Congress, Lisbon, Portugal, 5-9 September 1994; Volume IV, pp. 3013-3021.

4. Turgul, A.; Zarif, I.H. Correlation of mineralogical and textural characteristics with engineering properties of selected granitic rocks from Turkey. Eng. Geol. 1999, 51, 303-317.

5. Smith, M.R.; Collis, L. Aggregates: Sand, Gravel and Crushed Rock Aggregates for Construction Purposes; Spec. Publ. 17; The Geological Society: London, UK, 2001.

6. Miskovsky, K.; Tabora, D.M.; Kou, S.Q.; Lindqvist, P.A. Influence of the mineralogical composition and textural properties on the quality of coarse aggregates. J. Mater. Eng. Perform. 2004, 13, 144-150. [CrossRef]

7. Al-Oraimi, S.K.; Taha, R.; Hassan, H.F. The effect of the mineralogy of coarse aggregate on the mechanical properties of high-strength concrete. Constr. Build. Mater. 2006, 20, 499-503. [CrossRef]

8. Petrounias, P.; Rogkala, A.; Kalpogiannaki, M.; Tsikouras, B.; Hatzipanagiotou, K. Comparative study of physico-mechanical properties of ultrabasic rocks (Veria-Naousa ophiolite) and andesites from central Macedonia (Greece). Bull. Geol. Soc. Greece 2016, 50, 1989-1998. [CrossRef]

9. Giannakopoulou, P.P.; Tsikouras, B.; Hatzipanagiotou, K. The interdependence of mechanical properties of ultramafic rocks from Gerania ophiolitic complex. Bull. Geol. Soc. Greece 2016, 50, 1829-1837. [CrossRef] 
10. Rigopoulos, I.; Tsikouras, B.; Pomonis, P.; Hatzipanagiotou, K. The impact of petrographic characteristics on the engineering properties of ultrabasic rocks from northern and central Greece. Q. J. Eng. Geol. Hydrogeol. 2012, 45, 423-433. [CrossRef]

11. Petrounias, P.; Giannakopoulou, P.P.; Rogkala, A.; Stamatis, P.M.; Tsikouras, B.; Papoulis, D.; Lampropoulou, P.; Hatzipanagiotou, K. The Influence of Alteration of Aggregates on the Quality of the Concrete: A Case Study from Serpentinites and Andesites from Central Macedonia (North Greece). Geosciences 2018, 8, 115. [CrossRef]

12. Yilmaz, N.G.; Goktan, R.M.; Kibici, Y. Relations between some quantitative petrographic characteristics and mechanical strength properties of granitic building stones. Int. J. Rock Mech. Min. Sci. 2011, 48, 506-513. [CrossRef]

13. Rigopoulos, I.; Tsikouras, B.; Pomonis, P.; Hatzipanagiotou, K. The influence of alteration on the engineering properties of dolerites: The example from the Pindos and Vourinos ophiolites (northern Greece). Int. J. Rock Mech. Min. Sci. 2010, 47, 69-80. [CrossRef]

14. Diamantis, K.; Gartzos, E.; Migiros, G. Study on uniaxial compressive strength, point load strength index, dynamic and physical properties of serpentinites from Central Greece: Test results and empirical relations. Eng. Geol. 2009, 108, 199-207. [CrossRef]

15. Pola, A.; Crosta, G.; Fusi, N.; Barberini, V.; Norini, G. Influence of alteration on physical properties of volcanic rocks. Tectonophysics 2012, 566-567, 67-86. [CrossRef]

16. Ündül, Ö. Assessment of mineralogical and petrographic factors affecting petro-physical properties, strength and cracking processes of volcanic rocks. Eng. Geol. 2016, 210, 10-22. [CrossRef]

17. Gresens, R.L. Composition-volume relationships of metasomatism. Chem. Geol. 1967, 2, 47-65. [CrossRef]

18. Veniale, F.; van der Marel, H.D. An interstratified saponite-swelling chlorite mineral as a weathering product of lizardite rock from St. Margherita Staffora (Pavia Province), Italy. Beitr. Miner. Petrogr. 1963, 9, 198-245.

19. Wildman, W.E.; Jackson, M.L.; Whittig, L.D. Iron-rich montmorillonite formation in soils derived from serpentinites. Soil Sci. Soc. Am. Proc. 1968, 32, 787-794. [CrossRef]

20. Ducloux, J.; Mennier, A.; Velde, B. Smectite, chlorite and a regular interstratified chlorite-vermiculite in soils developed on a small serpentinite body Massif Central, France. Clay Miner. 1976, 11, 121-135. [CrossRef]

21. Garcia, A.; Delgado, M. Mineralogia de las fracciones arenosas de suelos desarrollados sobre serpentinas en la Sierra de Carratraca (Malaga). Anal. Edafol. Agrobiol. 1978, 37, 599-620.

22. Istok, J.D.; Harward, M.E. Influence of soil moisture on smectite formation in soils derived from serpentite. Soil. Sci. Soc. Am. J. 1982, 46, 1106-1108. [CrossRef]

23. Hurlbut, C.S.; Sharp, W.E. Dana's Minerals and How to Study Them (After Edward Salisbury Dana), 4th ed.; John Wiley \& Sons, Inc.: New York, NY, USA, 1998; pp. 248-257.

24. Escartin, J.; Hirth, G.; Evans, B. Strength of slightly serpentinized peridotites: Implications for the tectonics of oceanic lithosphere. Geology 2001, 29, 1023-1026. [CrossRef]

25. Frost, B.R.; Beard, J.S. On silica activity and serpentinization. J. Petrol. 2007, 48, 1351-1368. [CrossRef]

26. Shervais, J.W.; Kolesar, P.; Andreasen, K. A field and chemical study of serpentinization-Stonyford, California: Chemical flux and mass balance. Int. Geol. Rev. 2005, 47, 1-23. [CrossRef]

27. Deschamps, F.; Godard, M.; Guillot, S.; Hattori, K. Geochemistry of subduction zone serpentinites: A review. Lithos 2013, 178, 96-127. [CrossRef]

28. Malvoisin, B. Mass transfer in the oceanic lithosphere: Serpentinization is not isochemical. Earth Planet. Sci. Lett. 2015, 430, 75-85. [CrossRef]

29. Chidester, A.H.; Albee, A.L.; Cady, W.M. Petrology, Structure and Genesis of the Asbestos-Bearing Ultramafic Rocks of the Belvidere Mountain Area in Vermost; U.S. Geological Survey Professional Paper No 1016; U.S. Government Print Office: Washington, DC, USA, 1978.

30. Pohl, W. Large scale metallogenic features of Pan African in east Africa, Nubia and Arabia. Bull. Fac. Earth Sci. King Abdulaziz Univ. Jeddah 1984, 6, 592-601.

31. El-Gaby, S.; List, F.K.; Tehrani, R. Geology, evolution and metallogenesis of the Pan African belt in Egypt. In The Pan African Belt of Northeast Africa and Adjacent Areas; El-Gaby, S., Greling, R.O., Eds.; Vieweg: Braunschweig, Germany, 1988; pp. 17-68.

32. Hussein, A.A. Mineral deposits of Egypt. In The Geology of Egypt; Said, R., Ed.; Elsevier: Amsterdam, The Netherlands, 1990; pp. 511-566. 
33. Salem, I.A. Talc deposits at Rod El-Tom and Umm El-Dalalil areas, Eastern Desert. Egypt J. Geol. 1992, 36, 175-189.

34. Morad, S. Mica Alteration Reactions in Jurassic Reservoir sandstones from the Haltenbanken Area, offshore Norway. Clays Clay Miner. 1990, 38, 584-590. [CrossRef]

35. Bettison, L.A.; Schiffman, P. Compositional and Structural variations of phyllosillicates from the Point Soil ophiolite, California. Am. Mineral. 1988, 79, 671-695.

36. Stoch, I.; Sikora, W. Transformation of micas in the process of kaolinitization of granites and gneisses. Clays Clay Miner. 1976, 24, 156-162. [CrossRef]

37. Srodon, J.; Ebert, D.D. Illite. Rev. Mineral. 1984, 13, 495-544.

38. Innoue, A.; Utada, M. Further investigations of a conversion series of dioctahedral mica/smectite in the Shinzan hydrothermal alteration area, north- east Japan. Clays Clay Miner. 1983, 31, 401-412. [CrossRef]

39. Kranidiotis, P.; MacLean, W.H. Systematics of chlorite alteration at the Phelps Dodge massive sulfide deposit, Matagami. Quebec Econ. Geol. 1987, 82, 1898-1911.

40. Shikazono, N.; Kawahata, H. Compositional differences in chlorite from hydrothermally altered rocks and hydrothermal ore deposits. Can. Mineral. 1987, 25, 465-474.

41. Tiwari, B.; Ajmera, B. Consolidation and swelling behavior of major clay minerals and mixtures. Appl. Clay Sci. 2011, 54, 264-273. [CrossRef]

42. Bish, D.L.; Howard, S.A. Quantitative phase analysis using the Rietveld Method. J. Appl. Cryst. 1988, 21, 86-91. [CrossRef]

43. Bish, D.L.; Post, J.E. Quantitative mineralogical analysis using the Rietveld full pattern fitting method. Am. Mineral. 1993, 78, 932-940.

44. Bish, D.L.; Plotze, M. X-ray powder diffraction with emphasis on qualitative and quantitative analysis in industrial mineralogy. In Advances in the Characterization of Industrial Minerals; EMU Notes in Mineralogy; Mineralogical Society: London, UK, 2011; Volume 9, pp. 35-76.

45. McCusker, L.B.; Von Dreele, R.B.; Cox, D.E.; Louer, D.; Scardi, P. Rietveld refinement guidelines. J. Appl. Crystallogr. 1999, 32, 36-50. [CrossRef]

46. Hillier, S. Accurate quantitative analysis of clay and other minerals in sandstones by XRD: Comparison of a Rietveld and a reference intensity ratio (RIR) method and the importance of sample preparation. Clay Miner. 2000, 35, 291-302. [CrossRef]

47. Gualtieri, A.F. Accuracy of XRPD QPA using the combined Rietveld-RIR Method. J. Appl. Crystallogr. 2000, 33, 267-278. [CrossRef]

48. Rogkala, A.; Petrounias, P.; Tsikouras, B.; Hatzipanagiotou, K. New occurrence of pyroxenites in the Veria-Naousa ophiolite (north Greece): Implications on their origin and petrogenetic evolution. Geosciences 2017, 7, 92. [CrossRef]

49. Decourt, J.; Aubouin, J.; Savoyat, E. Le sillon mesohellenique et la zone pelagonienne. Bull. Soc. Geol. Fr. 1977, 1, 32-70.

50. Michailidis, K.M. Zoned chromites with high Mn-contents in the Fe-Ni-Cr-laterite ore deposits from the Edessa area in Northern Greece. Miner. Depos. 1990, 25, 190-197. [CrossRef]

51. Pe-Piper, G.; Piper, D.J.W. The Igneous Rocks of Greece. The Anatomy of an Orogen; Gebrder Borntaeger: Berlin, Germany, 2002.

52. Saccani, E.; Photiades, A.; Santato, A.; Zeda, O. New evidence for supra-subduction zone ophiolites in the Vardar zone of northern Greece: Implications for the tectonomagmatic evolution of the Vardar oceanic basin. Ofioliti 2008, 33, 65-85.

53. Boccaletti, M.; Manetti, P.; Peccerillo, A. The Balkanides as an Instance of Back-Arc Thrust Belt: Possible relation with the Hellinides. Geol. Soc. Am. Bull. 1974, 85, 1077-1084. [CrossRef]

54. Eleftheriadis, G.; Castorina, F.; Soldatos, T.; Masi, U. Geochemical and Sr-Nd isotopic evidence for the genesis of the Late Cainozoic Almopia volcanic rocks (Central Macedonia, Greece). Mineral. Petrol. 2003, 78, 21-36. [CrossRef]

55. Clément, B. Evolution Géodynamique d'un Secteur des Hellénides Internes: L'Attique-Béotie (Gréce Continentale). Ph.D. Thesis, University of Lille, Lille, France, 1983.

56. Vacondios, I. Etude Metallogenique des Chromites Liees aux Ophiolites de Type Mediterranee Occdentale ou Orientale: Le Chromites de Tinos et des Gerannees. Ph.D. Thesis, University of Patras, Patras, Greece, 1997. 
57. Danelian, T.; Robertson, A.H.F. Palaeogeographic implications of the age of radiolarian-rich sediments in Beotia (Greece). Bull. Geol. Soc. Greece 1998, 32, 21-29.

58. Zachariadis, P.; Kostopoulos, D.; Reischmann, T.; Himmerkus, F.; Matukov, D.; Sergeev, S. U-Pb ion-microprobe zircon dating of subduction-related magmatism from northern Greece: The ages of the Guevgueli, Thessaloniki and Chalkidiki igneous complexes. Geophys. Res. Abstr. 2006, 8, 055560.

59. Saccani, E.; Bortolotti, V.; Marroni, M.; Pandolfi, L.; Photiades, A.; Principi, G. The Jurassic association of backarc basin ophiolites and calc-alkaline volcanics in the Guevgueli complex (Northern Greece): Implication for the evolution of the Vardar zone. Ofioliti 2008, 33, 209-227.

60. Freyberg, B.V. Geologie des Isthmus von Korinth. Erlanger Geologische Abhandlungen, 95; Junge and Sohn, Universitats-Buchdruckerei: Enlangen, Germany, 1973.

61. EN 932-1. Part 1: Composition, Specifications and Conformity Criteria for Common Cements; European Standard: Pilsen, Czech Republic, 2011.

62. EN 932. Part 3: Procedure and Terminology for Simplified Petrographic Description; European Standard: Pilsen, Czech Republic, 1996.

63. BSI (British Standards Institution). Part 1: Methods for Determination of Particle Size and Shape. In Methods for Sampling and Testing of Mineral Aggregates, Sands and Fillers; BSI: London, UK, 1975.

64. AASHTO (American Association of State Highway and Transportation Officials). Standard Method of Test for Total Evaporable Moisture Content of Aggregate by Drying; T255; AASHTO: Washington, DC, USA, 2000.

65. ISRM Suggested method for determining point load strength. Int. J. Rock Mech Min. Sci. Geomech. Abstr. $1985,22,51-62$.

66. ASTM C-131. In Resistance to Abrasion of Small-Size Coarse Aggregate by Use of the Los Angeles Machine; American Society for Testing and Materials: Philadelphia, PA, USA, 1989.

67. ASTM D-2938. In Standard Test Method of Unconfined Compressive Strength of Intact Rock Core Specimens; Annual Book of Standards, 4.08; American Society for Testing and Materials: Philadelphia, PA, USA, 1986.

68. Sabatakakis, N.; Koukis, G.; Tsiambaos, G.; Papanakli, S. Index properties and strength variation controlled by microstructure for sedimentary rocks. Eng. Geol. 2008, 97, 80-90. [CrossRef]

69. Diamantis, K.; Gartzos, E.; Migiros, G. Influence of petrographic characteristics on physico-mechanical properties of ultrabasic rocks from central Greece. Bull. Eng. Geol. Environ. 2014, 73, 1273-1292. [CrossRef]

70. Undul, O.; Turgul, A. On the variations of geo-engineering properties of dunites and diorites related to weathering. Environ. Earth Sci. 2016, 75, 1326. [CrossRef]

71. Weinert, H.H. Basic Igneous Rocks in Road Foundations; CSIR Research Report No. 218; Soil Mechanics Division, National Institute for Roads Research: Pretoria, South Africa, 1964; p. 47.

72. Weidler, P.G.; Luster, J.; Schneider, J.; Sticher, C.H.; Gehring, A.U. The Rietveld method applied to the quantitative mineralogical and chemical analysis of a ferralitic soil. Eur. J. Soil Sci. 2008, 49, 95-105. [CrossRef]

73. Taylor, R.K.; Smith, T.J. The engineering geology of clay minerals; swelling, shrinking and mudrock breakdown. Clay Miner. 1986, 21, 235-260. [CrossRef] 